\title{
A D-section and a tin whistle: A tribute to Prof. Geoff Hope
}

\section{Matthew Prebble}

Department of Archaeology and Natural History, Research School of Pacific and Asian Studies, Australian National University, Canberra, Australia

matthew.prebble@anu.edu.au

\section{Janelle Stevenson}

Department of Archaeology and Natural History, Research School of Pacific and Asian Studies, Australian National University, Canberra, Australia

\section{Simon Haberle}

Department of Archaeology and Natural History, Research School of Pacific and Asian Studies, Australian National University, Canberra, Australia

After more than 40 years of academic research and teaching in Quaternary Science, Prof. Geoff Hope retired in June 2009. As an undergraduate student at the University of Melbourne in the 1960s, Geoff studied the natural sciences under such greats as Ray Specht. He later became one of a pioneering band of researchers to pursue palynology in Australia, starting with a Master's project on the peatlands of Wilsons Promontory, investigating the history of Nothofagus forest and aboriginal plant use. For his $\mathrm{PhD}$ research, he made the big leap into New Guinea, exploring glaciation as a driver of vegetation and climate change. Obtaining a Queen Elizabeth Fellowship, Geoff completed his PhD at the Department of Biogeography and Geomorphology at the ANU, under Donald Walker and Joe Jennings. To undertake his field work in 1972, Geoff lived for the whole year in a small ANU field hut (that still stands to this day) at the base of Mount Wilhelm, next to Lower Pindaunde Lake. From there, he made regular trips down to Kundiawa, the capital of Simbu Province, to obtain supplies and to submit samples of 'black sludge' for radiocarbon dating, as Richard Gillespie recalls:

'The year 1972 is probably best remembered by some Australians for the first Sunbury music festival, for others the Aboriginal Tent Embassy established on the lawns of Parliament House, the election of Gough Whitlam, or that catalogue sales for a Tutankhamun exhibition in London realised more than gate takings from the five-test Ashes series in England. Very few would have expected that intrepid Australians were 
interrogating sediments in the high mountains of western New Guinea, for reasons no doubt best known to themselves. My knowledge of this event came from several bags of non-descript dirt, mostly black, some with woody bits, which landed on my desk at the Sydney University Radiocarbon Laboratory.

Not long after construction of that lab began in 1970, by MSc student Ian Fraser and $\mathrm{PhD}$ student Gillespie, our supervisor Assoc. Prof. Richard Temple attached a small typed notice to the door, respectfully dedicating the venture to former student Glynn Parfitt, a fundamentalist Plymouth Brethren devotee who had unsuccessfully tried to build a gas counting radiocarbon system to prove that the creation date calculated by Bishop Ussher was correct. We eventually got everything working and the first SUA-dates were published in late 1972, containing mainly modern standard measurements and cross-check samples provided as blind tests by Henry Polach from the ANU Radiocarbon Research Laboratory.

Among the many other samples arriving at the lab in 1972, but not making the first date list, were the bags of dirt from Jim Peterson and Geoffrey Hope. I was never sure why those samples came to Sydney, I had never heard of Hope or Peterson, and later suspected that Henry Polach (busy on the biggest game in town, the Mungo dates in Bowler et al. 1972) had farmed out the black sludge from New Guinea to me for a shot at making an impression on clients willing to pay good money for dates. I think we were charging $\$ 60$ per sample.

Results were sent back (by Telex!) less than two weeks after they arrived at the lab, while the Peterson and Hope team was still in the field. Not that such service was on the same scale available to Americans: samples and radiocarbon dates were shuttled by car, on a weekly turn-around, between Rainer Berger's UCLA lab and massive excavations at Tule Springs, Nevada, in 1969. And scintillation counting pioneers Jerry Stipp and Murry Tamers built a mobile radiocarbon lab-on-a-truck, providing an overnight onsite service; later they built a radiocarbon date factory called Beta Analytic.

Some of the samples submitted by Hope and Peterson were among the first couple of dozen unknowns processed in the Sydney lab, although publication of these and later samples from the same region was delayed for four years (Gillespie and Temple 1976; Hope et al. 1976). There were more exciting samples in the same datelist, from archaeological sites at Malakunanja, Deaf Adder Gorge and Devil's Lair, but the tropical glacier and pollen-related samples from New Guinea were given the best available treatment in 1972. Thirty-seven years on, and I'm still dealing with sediments collected by Geoffrey Hope and others in New Caledonia (Stevenson et al. this volume), so I have to ask: when will this black sludge obsession cease, and what might the uncertainty on that date be?'

Geoff's primary research outcomes from his $\mathrm{PhD}$ resulted in some of his most widely acclaimed research. According to Paul Hesse (2006), his 1976 Journal of Ecology paper sits in the Top 10 best-ever Quaternary papers from Australasia. The paper traces tropical tree-line movement through dated records extending to the late Pleistocene. According to Paul, the substantial depression of temperatures $(-8 \mathrm{C})$ 'has remained as an inspiration and frustration to palaeoclimatologists' attempts to understand climate change in the tropics ever since'.

After his PhD, Geoff was appointed a Lecturing Fellow in the Department of Geography, ANU, in 1978. Since that time, Geoff has been instrumental in engaging researchers from different fields in the wonders of New Guinea's natural and cultural history. He first introduced Tim Flannery to these marvels in 1982 on an expedition he organised to Kosipe Mission to explore the Pleistocene palaeoecology of the Ivane basin. In Tim's fascinating account of his adventures in New Guinea, Throwim Way Leg (1998), he describes Geoff as the most inspiring 
teacher of natural history he has known. As Flannery's book illustrated, being introduced to New Guinea by Geoff not only involved delving knee deep into swamps in the rugged mountains or mosquito-plagued lowlands, but also led to real adventure and irresistible opportunities for students to experience one of the most remote and rugged regions on earth. Also joining Geoff in New Guinea in the 1980s was plant ecologist Jenny Read, researching Nothofagus ecology (e.g. Read and Hope 1989). Jenny recalls one incident as a not uncommon occurrence in the highlands:

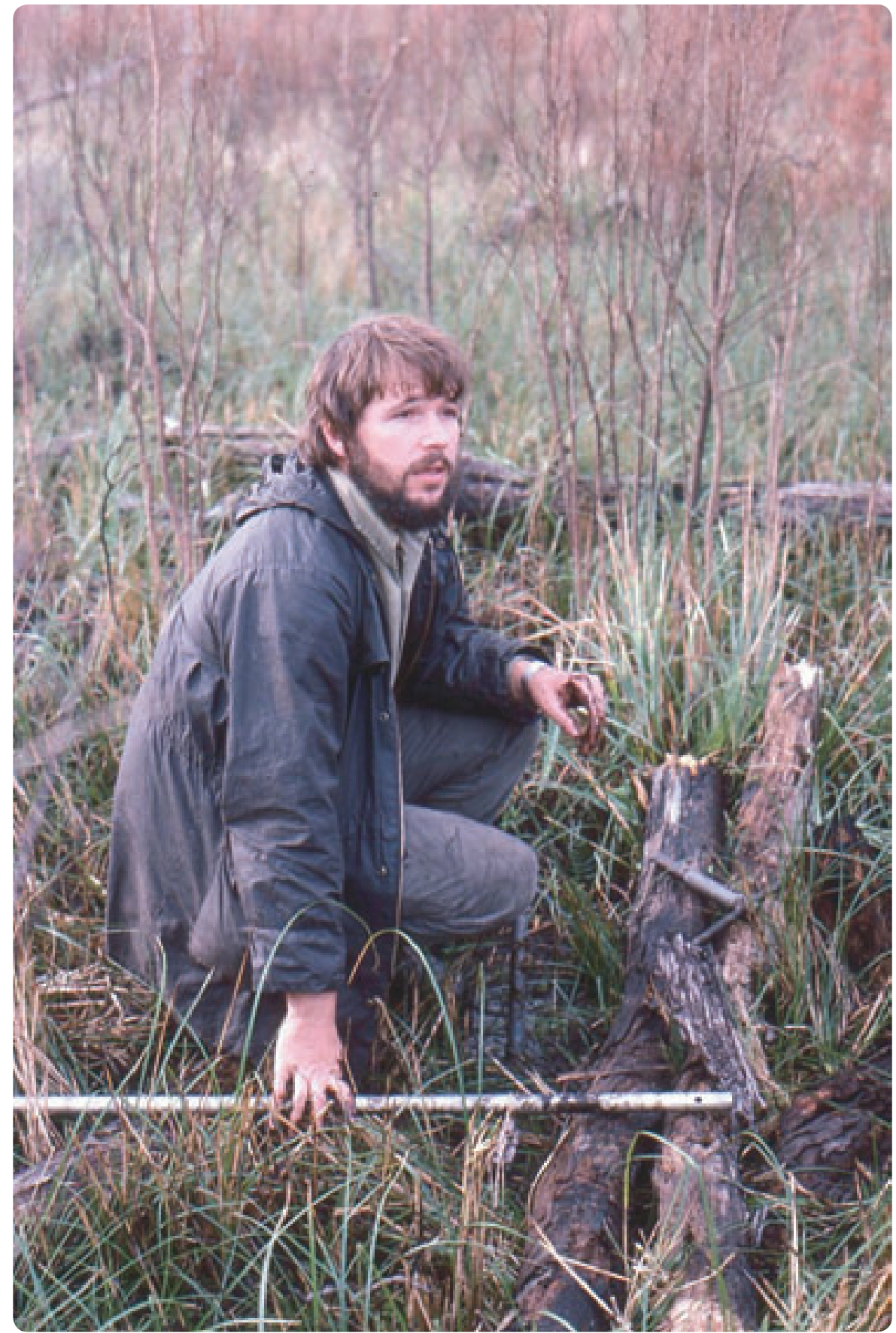

Figure 1. Geoff coring on Hunter Island, northwest Tasmania in 1976. Photograph Sandra Bowdler

'Geoff was collecting sediment cores from Nurenk Swamp, and some of us who had been conducting vegetation surveys in the area headed back to our vehicle early. When we arrived we were greeted by a crowd who informed us that they would kill us all 


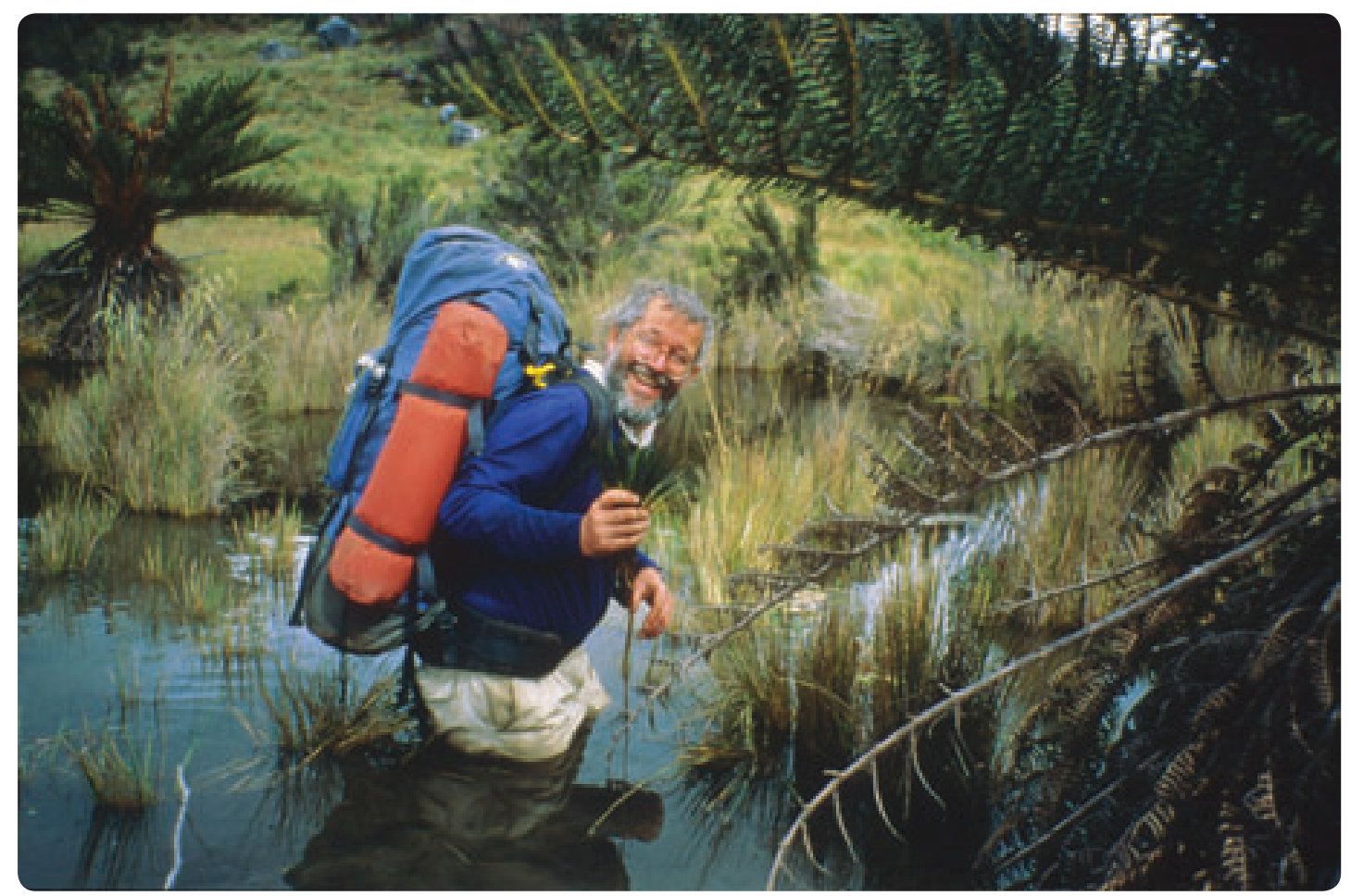

Figure 2. Geoff trudging through his beloved bogs on the Kemabu Plateau, a high-altitude area covered with thick glacial deposits to the north of Mount Jaya, West Papua, 1993

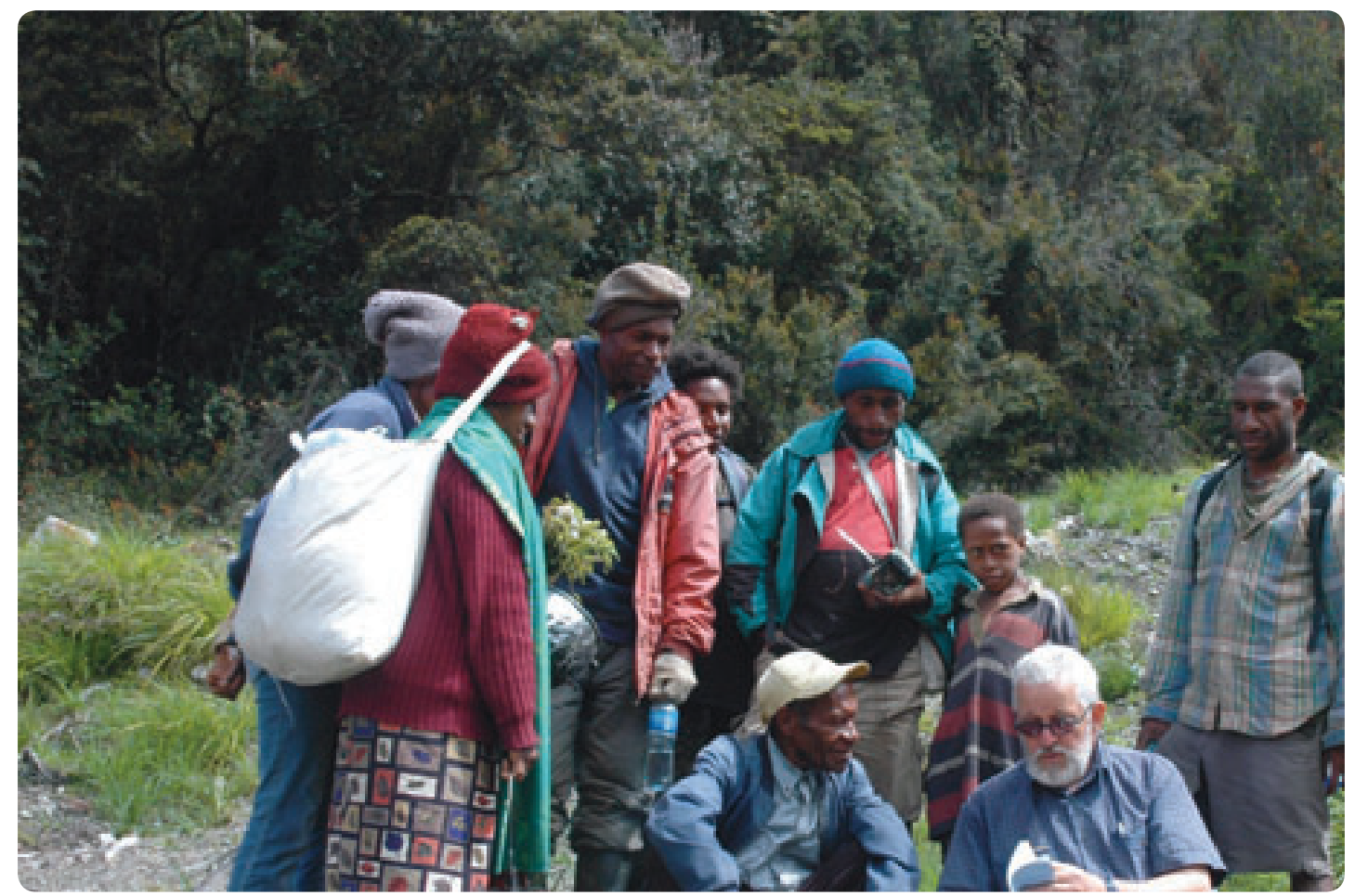

Figure 3. Geoff on Mount Wilhelm in 2007 reminiscing and resting with members of the clan who worked with him during his PhD fieldwork on the mountain in the early 1970s. Photograph Simon Haberle 
unless we gave them $\$ 100$. I went back into the swamp to get Geoff (for his pidgin skills) and when he arrived he spent a couple of hours negotiating them down to $\$ 16$ ! I didn't catch all of his arguments, but foreign aid, Australian development assistance, etc all played a part. I think we were all just sitting quietly (keeping our heads down). There are a few morals in this, depending on how you look at it. Somehow, though, I imagine that nearly all of us [who have worked with Geoff] have a similar story. Mostly when I think of Geoff I sadly think of a take-away stand [kai bar] in Mount Hagen that had a tank full of boiling fat and brisket and similar delights, and Geoffs excitement at such.'

Everyone will be pleased to know that Geoff has been a successful vegetarian for many years, mainly at the insistence of partner Bren, who is clearly aware of the perils of kai bars and Ox \& Palm Bully Beef?

Geoff has often described himself as a 'plant historian', contrary to how some of his colleagues have seen him. The botanist Jim Croft, when working with Geoff on the botany and vegetation of highland New Guinea in the 1970s and '80s, found that:

'He was more interested in getting knee deep in high-altitude bogs and he had patiently explained that he wasn't really interested in and did not see plants in the field - he was after vegetation, a thing that botanists never saw.'

Geoff has continued to work in Papua New Guinea ever since, perhaps in part for his interest in the natural history and the impressive diversity of people and cultures in the region, but also because of his family heritage. His mother came from a sugar-cane growing family who lived in New Guinea during the early colonial days. To Jack Golson, Geoff represents part of a strong historical lineage of great multidisciplinary scientists who pioneered research in Papua New Guinea. His most recent work has been refocusing on the Owen Stanley Range, to his relief, publishing data which he obtained back in 1974 (Hope 2009). In 2007, Geoff led a group of international scientists on a two-week trip through the highlands of Papua New Guinea, visiting many of the old haunts from his $\mathrm{PhD}$ days. This included walking, perhaps a little slower this time, to the alpine grasslands of Mount Wilhelm in the Chumbu Province. As word went around the valley that he was there, it was with little surprise that the group soon met up with the people with whom Geoff had worked so closely in the 1970s (see Figure 3), many remembering the work that he did in opening up the region for researchers to return through the past 40 years. He returns once more to Mount Wilhelm this year, with Tim Barrows and Brad Pillans, in their attempt to further substantiate the timing of peak glacial conditions during the Last Glacial Maximum in Papua New Guinea.

He joined the Department of Biogeography and Geomorphology in the Research School of Pacific Studies, ANU, led by John Chappell, as Senior Fellow, in 1990 and was head of the Department of Archaeology and Natural History from 1998 to 2003. Five years as head of an archaeology department still hasn't earned him the title 'archaeologist'. Geoff often recalls working on Kangaroo Island in the 1970s with Ron Lampert while conducting geomorphological surveys and swamp coring. On one occasion, Geoff picked up what he thought was clearly a waisted blade. Ron explained that when in Geoff's hands 'this is not an artefact it's merely a stone, in the hands of an archaeologist it's an artefact!'.

Geoff's research interests are broad and they have taken him across Australia, to the rainforests of Southeast Asia and to the remote parts of the Pacific Islands. Patrick Nunn writes of Geoff's contribution to the palaeoecology of Fiji and endurance in the field: 


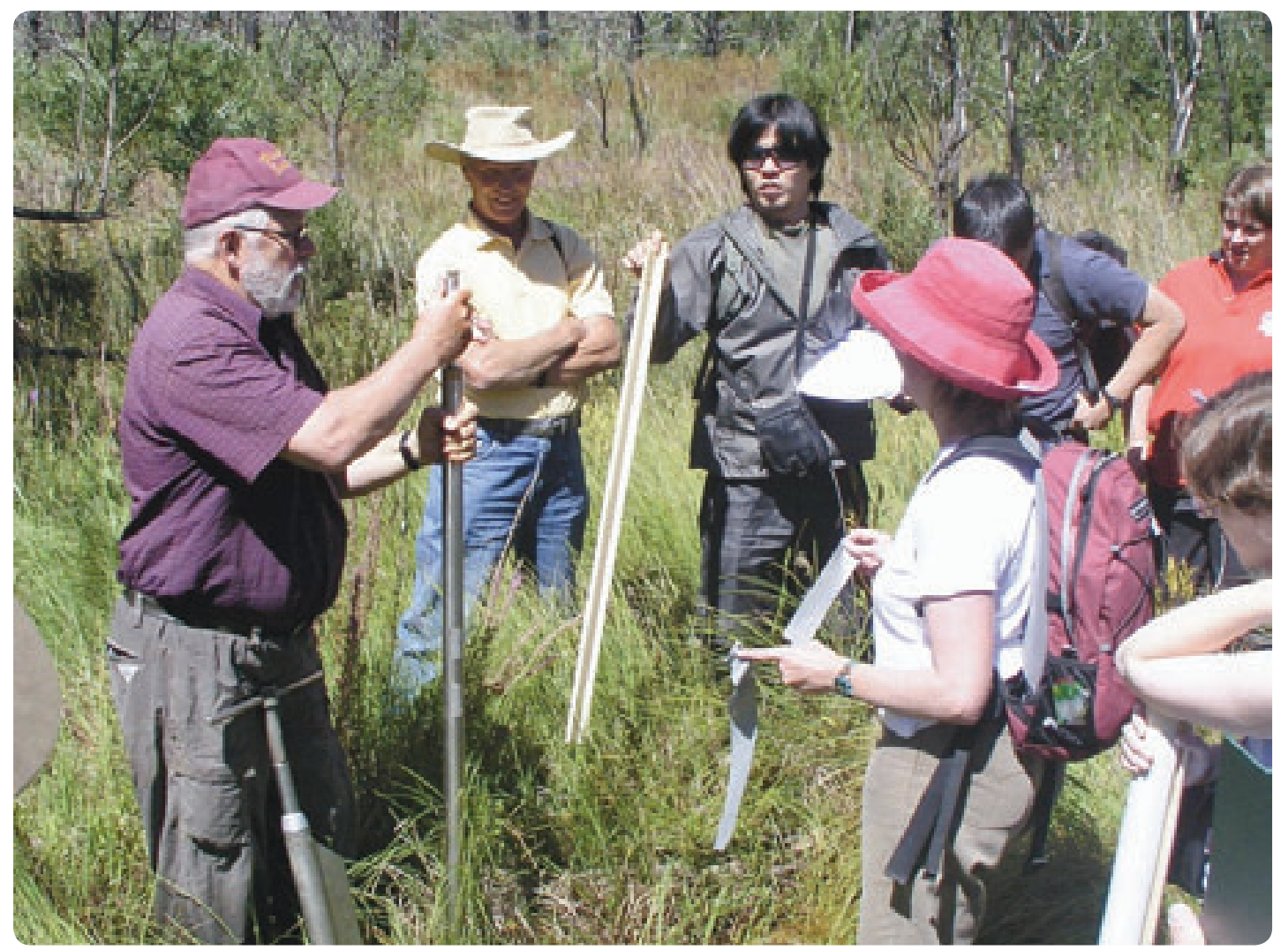

Figure 4. Geoff teaching undergraduate students from the ANU in an area affected by the 2003 fires in the Namadgi National Park, ACT. Photograph Simon Haberle

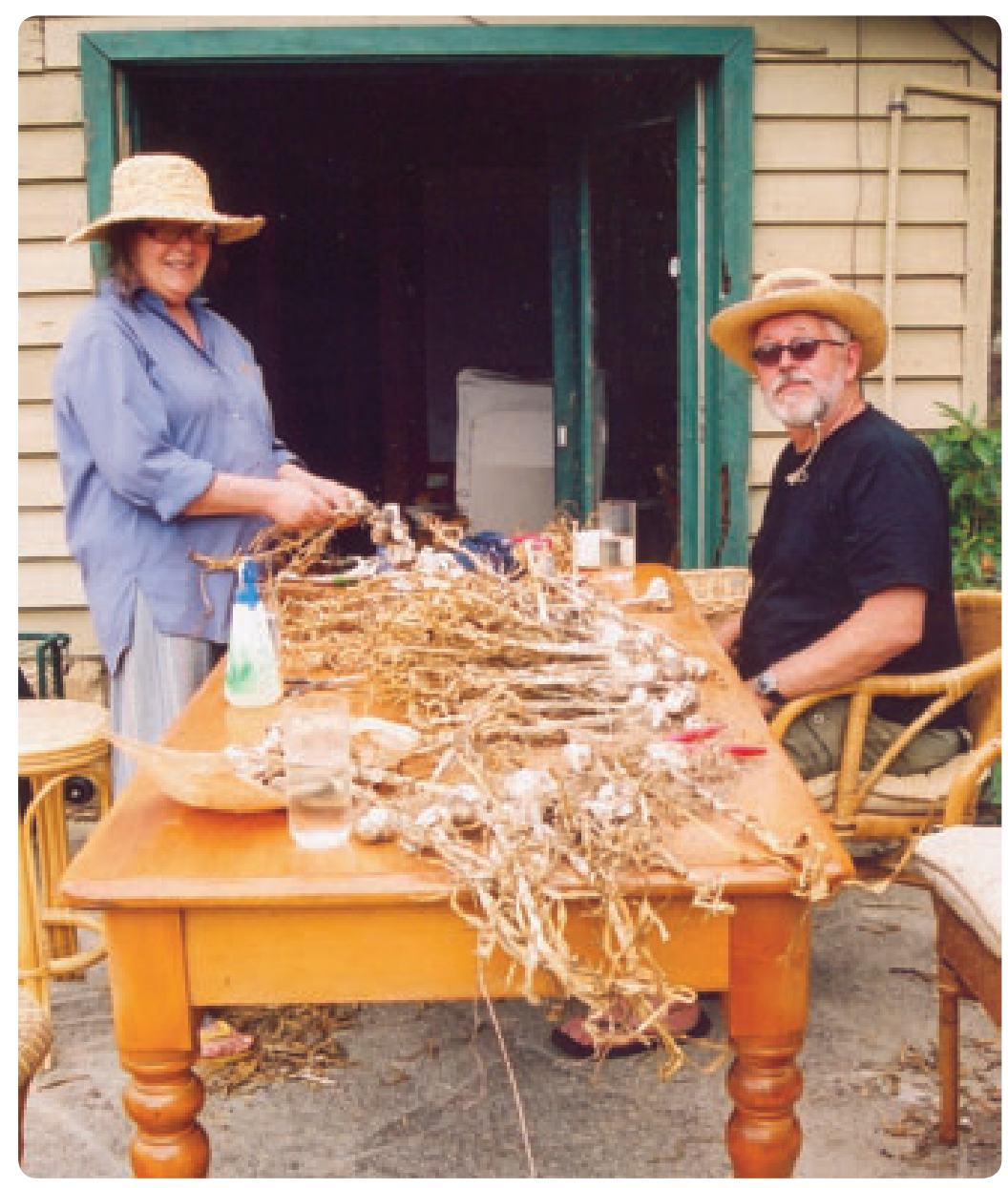

Figure 5. Geoff with partner Bren and a harvest of garlic at their Bunga property on the south coast of NSW 
'In the Vanua Balavu islands in 2000, the site on which the punishment squad [Patrick's students] focused their attention was a sinkhole named Cavaura. Geoff recognized at once the extraordinary potential of the sediment sequence likely to exist in the sediments in the centre of Cavaura and was determined to core them. With our eyes almost popping out in horror, we contemplated mutiny as we followed Geoff out to the very centre. With water up to our chests (for some of us), we dutifully pushed the hated corer further and further down into the scarcely-yielding sediments beneath. Down, down, down and finally, turn, then pull out. A process accompanied by a large subterranean belch, the black mud oozed out of the D-section corer. With astonishing equanimity for someone in his position, Geoff would have us hold the D-section horizontally while he cut the mud carefully into sections and bagged them.

One day in Cavaura was unusually hot. Three of us were with Geoff in the centre of the lake coring. The water and the mud were burning us, even to the point of losing feeling in our legs and midriffs. Mentioned this to Geoff and he laughed (as though he were not even uncomfortable!), saying that in Papua New Guinea you have all this plus a couple of eight-foot crocodiles!

Lunch at Cavaura, precariously seated in the hornet-infested rock shelters that lined the side of the sinkhole, was invariably enlivened by Geoff's piping. Just when we thought nothing else could possibly impact our sensibilities, out would come a penny whistle and Geoff would play a jig. Enclosed by limestone cliffs, framing the blue sky above us, an eerie quiet all around, Geoff's music would instantly enthuse us. Reminding us that there was another world beyond Cavaura into which, after a few more hours in that watery hell, we would joyfully re-enter, the music gave us new hope and the willpower that we needed to finish the job.'

Geoff continues to pull out his tin whistle at odd occasions. On one of these occasions when Geoff was heading out of Brisbane airport he left his whistle in a carry-on bag and was abruptly asked by the security officer 'what's this for?' Geoff replied 'This!' and proceeded to play a jig to the joy of all.

Geoff's practical attitude to life and work is captured by this anecdote from Sue O'Connor and fellow archaeologist Matthew Spriggs, on an expedition to East Timor with Geoff in 2000. United Nations personnel had warned them they would be unable to get to Tutuala village, which is on the eastern tip of the island, because Lake Ira Lalaro had flooded, cutting off the road and isolating the region for months. UN vehicles were reluctant to venture on to the flooded roads. There was no stopping Geoff, 'We're Australian,' he said. 'No wozzas, we can get through this easy.' He then opened out his tent, took out the flysheet and proceeded to wrap it around the front grille of the vehicle. They triumphantly made the crossing and the three were saluted by locals as they drove down Tutuala's only street.

One of the most admirable characteristics of Geoff is his inclusiveness, both of his family, students and colleagues. Geoff's family have joined him on many expeditions to remote and often precarious locations, as well as welcoming many of us into their home for one of those not to be missed Greenhood Place gatherings. His 'can do' approach to life has meant that research gets done and everyone gets involved. In an interview by The Australian (17.2.2010), Geoff suggested that he was not retiring but entering a new phase as 'a gentleman scientist'. Geoff was recently awarded emeritus status at the ANU and all of us wish him well, and expect him to continue to probe the depths of Australasia's landscape history. To answer Richard's query, the quest for more 'black sludge' will never end! 


\section{Other papers mentioned in the text}

Bowler, J.M., A.G. Thorne and H.A. Polach 1972. Pleistocene man in Australia: Age and Significance of the Mungo Skeleton. Nature 240:48-50.

Flannery, T.F. 1998. Throwim Way Leg: Tree-Kangaroos, Possums, and Penis Gourds - On the track of unknown mammals in wildest New Guinea. New York: Atlantic Monthly Press.

Gillespie, R. and R.B. Temple 1976. Sydney University Natural Radiocarbon Measurements III. Radiocarbon 18:96-109.

Hesse, P. 2006. The Australian Quaternary top 10. Quaternary Australasia 23:12-15

Stevenson, J., Gillespie, R., G.S. Hope, Jacobsen, G., Fallon, S. and V. Levchenko 2010. The archaic and puzzling record of Lake Xere Wapo, New Caledonia. In Simon G. Haberle, Janelle Stevenson and Matthew Prebble (editors), Altered Ecologies: Fire, Climate and Human Influence on Terrestrial Landscapes, Terra Australis 32. ANU E-Press, Canberra, The Australian National University, this volume. 


\section{Publications of Geoffrey S. Hope}

Howard, T.M. and G.S. Hope 1970. The present and past occurrence of beech (Nothofagus cunninghamii Oerst.) at Wilsons Promontory, Victoria, Australia. Proceedings of the Royal Society of Victoria 83:199-210.

Hope, G.S. and P.J.F. Coutts 1971. Past and present aboriginal food resources at Wilson's Promontory. Mankind 8:104-114.

Hope, G.S. and G.K. Thomson 1971. The vegetation of Cliffy Island, Victoria, Australia. Proceedings of the Royal Society of Victoria 84:121-128.

Peterson, J.A. and G.S. Hope 1972. A lower limit and maximum age for the last major advance of Carstensz glaciers, West Irian. Nature 240:36-37.

Galloway, R.W., G.S. Hope, E. Loffler and J.A. Peterson 1973. Late Quaternary glaciation and periglaciation phenomena in Australia and New Guinea. In E.M. van Zinderen Bakker (ed.) Palaeoecology of Africa, the surrounding Islands and Antarctica, pp125-138. Capetown, South Africa: Balkema.

Hope, G.S., J.A. Peterson and R. Mitton 1973. Recession of the minor ice fields of Irian Jaya. Zeitschrift fur Glestcherkunde and Glazialgeologie 9:73-87.

Scarlett, N.H., G.S. Hope and D.M. Calder 1974. Natural history of the Hogan Group. 3. Floristics and plant communities. Proceedings of the Royal Society of Tasmania 107:83-98.

Hope, G.S. 1974. The vegetation history from 6000 B.P. to present of Wilsons Promontory, Victoria, Australia. New Phytologist 73:1035-1053.

Hope, G.S. and J.A. Peterson 1975. Glaciation and vegetation in the high New Guinea mountains. Bulletin of the Royal Society of New Zealand 13:153-162.

Schodde, R., J. van Tets, C.R. Champion and G.S. Hope 1975. Birds of Carstensz glaciers. Ети 75:65-72.

Hope, G.S. 1976. Palaeoenvironments for man in New Guinea. In R.L. Kirk and R.F. Thorne (eds) The Origins of the Australians, pp29-53. Canberra: Institute of Aboriginal Studies.

Hope, G.S. 1976. Vegetation. In G.S. Hope, J.A. Peterson, I. Allison and U. Radok (eds) The Equatorial Glaciers of New Guinea (Results of the 1971-1973 Australian Universities' Expeditions to Irian Jaya: survey, glaciology, meteorology, biology and palaeoenvironments, pp113-172. Rotterdam: A.A. Balkema.

Hope, G.S. 1976. Mt Jaya: the area and its exploration. In G.S. Hope, J.A. Peterson, I. Allison and U. Radok (eds) The Equatorial Glaciers of New Guinea (Results of the 1971-1973 Australian Universities' Expeditions to Irian Jaya: survey, glaciology, meteorology, biology and palaeoenvironments, pp1-14. Rotterdam: A.A. Balkema.

Hope, G.S. and J.H. Hope 1976. Man on Mt Jaya. In G.S. Hope, J.A. Peterson, I. Allison and U. Radok (eds) The Equatorial Glaciers of New Guinea (Results of the 1971-1973 Australian Universities' Expeditions to Irian Jaya: survey, glaciology, meteorology, biology and palaeoenvironments, pp225-238. Rotterdam: A.A. Balkema.

Hope, G.S. and J.A. Peterson 1976. Palaeoenvironments. In G.S. Hope, J.A. Peterson, I. Allison and U. Radok (eds) The Equatorial Glaciers of New Guinea (Results of the 19711973 Australian Universities' Expeditions to Irian Jaya: survey, glaciology, meteorology, biology and palaeoenvironments, pp173-206. Rotterdam: A.A. Balkema.

Hope, G.S. 1976. The vegetational history of Mt Wilhelm, Papua New Guinea. Journal of Ecology 64:627-663.

Bowler, J.M., G.S. Hope, J.N. Jennings, G. Singh and D. Walker 1976. Late Quaternary climates of Australia and New Guinea. Quaternary Research 6:359-394.

Bowler, J.M., G.S. Hope, J.N. Jennings, G. Singh and D. Walker 1978. Reply to comment by G. E. Williams. Quaternary Research 9:114-115.

Hope, G.S. 1978. The Late Pleistocene and Holocene vegetational history of Hunter Island, North-Western Tasmania. Australian Journal Botany 26:493-514. 
Hughes, P.J., G.S. Hope, M. Latham and M. Brookfield 1979. Prehistoric man-induced degradation of the Lakeba landscape: evidence from two inland swamps. In H.C. Brookfield (ed.) Lakeba: environmental change, population and resource use, pp93-111. Island Reports, UNESCO/UNFPA.

Hope, G.S. 1980. Historical influences on the New Guinea flora. In P. van Royen (ed.) Alpine flora of New Guinea, pp223-248. Vaduz: Cramer Verlag.

Hope, G.S. 1980. Tropical mountains in retrospect and prospect. In J.N. Jennings and G. Linge (eds) Of time and place, pp153-169. Canberra: ANU Press.

Hope, G.S. 1980. New Guinea mountain vegetation communities. In P. van Royen (ed.) Alpine flora of New Guinea, pp153-222. Vaduz: Cramer Verlag.

Hope, G.S. 1982. Pollen from archaeological sites: a comparison of swamp and open archaeological site pollen spectra at Kosipe Mission, Papua New Guinea. In W. Ambrose and P. Duerden (eds) Archaeometry: an Australian perspective, pp211-219. Canberra: Department of Prehistory, Research School of Pacific Studies, Australian National University.

Hope, G. and M. Spriggs 1982. A preliminary pollen sequence from Aneityum Island, southern Vanuatu. Bulletin of the Indo-Pacific Prehistory Association 2:88-94.

Walker, D. and G.S. Hope 1982. Late Quaternary vegetation history. In J.L. Gressitt (ed) Biogeography and ecology of New Guinea, pp263-287. The Hague: Junk.

Hope, G.S. 1983. Coastal southern Australia. In J. Chappell and A. Grindrod (eds) CLIMANZ: Quaternary climatic history of Australia, pp12, 34, 56, 74, 98. Canberra: Department of Biogeography and Geomorphology, Australian National University.

Hope, G.S. 1983. New Guinea. In J. Chappell and A. Grindrod (eds) CLIMANZ: Quaternary climatic history of Australia, pp 12, 35, 55, 75, 97. Canberra: Department of Biogeography and Geomorphology, Australian National University.

Hope, G.S. 1983. The vegetation changes of the last 20,000 years at Telefomin, Papua New Guinea. Journal of Tropical Geography 4:25-33.

Hope, G.S., J. Golson and F.J. Allen 1983. Palaeoecology and prehistory in New Guinea. Journal of Human Evolution 12:37-60.

Hope, G.S., J. Golson and J. Allen 1983. Palaeoecology and prehistory in New Guinea. Journal of Human Evolution 12:37-60.

Hope, G.S. 1984. Australian environmental change: timing, directions, magnitudes and rates. In P.S. Martin and R.G. Klein (eds) Pleistocene extinctions: a prehistoric revolution, pp681690. Tucson, Arizona: University of Arizona.

Gillieson, D., P. Gorecki and G. Hope 1985. Prehistoric agricultural systems in a lowland swamp, Papua New Guinea. Archaeology in Oceania 20:32-37.

Hope, G.S., P.J. Hughes and J. Russell-Smith 1985. Geomorphological fieldwork and the evolution of the landscape of Kakadu National Park. In R. Jones (ed.) Archaeological research in Kakadu National Park, pp229-240. Canberra: Australian National University \& National Parks and Wildlife.

MacPhail, M.K. and G.S. Hope 1985. Late Holocene mire development in montane southeastern Australia: a sensitive climatic indicator. Search 15:344-348.

Gibson, N. and G.S. Hope 1986. On the origin and evolution of Australasian alpine cushion plants. In B.A. Barlow (ed) Flora and fauna of alpine Australasia, pp 62-91. Melbourne: CSIRO.

Hope, G.S. 1986. Development of present day biotic distributions in the New Guinea mountains In B.A. Barlow (ed). Flora and fauna of alpine Australasia, pp129-145. Melbourne: CSIRO.

Hope, G., D. Gillieson and J. Head 1988. A comparison of sedimentation and environmental change in New Guinea shallow lakes. Journal of Biogeography 15:603-618. 
Gillieson, D. and G.S. Hope 1989. Development of the Mountain Ok environment. In B. Craig and D. Hyndman (eds) Children of Afek: tradition and change among Mountain Ok of Central New Guinea, pp27-34. Sydney: Oceania Monographs.

Gillieson, D., G. Hope and J. Luly 1989. Environmental change in the Jimi Valley. In P. Gorecki and D.S. Gillieson (eds) A crack in the spine, prehistory and ecology of the Jimi-Yuat Valley, Papua New Guinea, pp105-122. Townsville: James Cook University.

Hope, G.S. 1989. Climatic implications of timberline changes in Australasia from 30000 BP to present. In T. Donnelly and R. Wasson (eds) CLIMANZ 3, pp91-99. Canberra: CSIRO Division of Water Research.

Hope, G.S. and J.B. Kirkpatrick 1989. The ecological history of Australian forests. In K. Frawley and N. Semple (eds) Australia's ever changingforests, pp3-22. Canberra: Department of Geography and Oceanography, Australian Defence Force Academy.

Read, J. and G.S. Hope 1989. Foliar Frost-Resistance of Some Evergreen Tropical and Extratropical Australasian Nothofagus Species. Australian Journal Botany 37:361-373.

Haberle, S.G., G.S. Hope and Y. DeFretes 1991. Environmental change in the Baliem Valley, montane Irian Jaya, Republic of Indonesia. Journal of Biogeography 18:25-40.

Swadling, P. and G.S. Hope 1992. Environmental change in New Guinea since human settlement. In J. Dodson (ed.) The naive lands - prehistory and environmental change in the South West Pacific, pp13-42. Cheshire: Longman.

Hope, G., T. Flannery and Boeardi 1993. A preliminary report of changing Quaternary mammal faunas in subalpine New Guinea. Quaternary Research 40:117-126.

Hope, G.S. 1994. Quaternary vegetation. In R.S. Hill (ed.) History of the Australian vegetation. Cretaceous to recent, pp368-389. Cambridge: Cambridge University Press.

Thomas, I. and G.S. Hope 1994. An example of Holocene stability from Camerons Lagoon, a new treeline site on the Central Plateau, Tasmania. Australian Journal of Ecology 19:150-158.

Hope, G. and J. Tulip 1994. A long vegetation history from lowland Irian Jaya, Indonesia. Palaeogeography, Palaeoclimatology, Palaeoecology 109:385-398.

Hope, G.S. 1995. Australian Quaternary palaeoecology and its relevance to current issues of biodiversity. Australasian Biotechnology 5:220-224.

Hope, G.S. and J. Golson 1995. Late Quaternary change in the mountains of New Guinea. Antiquity 69:818-830.

Markgraf, V., M. McGlone and G. Hope 1995. Neogene paleoenvironmental and paleoclimatic change in southern temperate ecosystems -- a southern perspective. Trends in Ecology and Evolution 10:143-147.

Hope, G.S. 1996. History of Nothofagus in New Guinea and New Caledonia. In T.T. Veblen, R.S. Hill and J. Read (eds) The ecology and biogeography of Nothofagus forests, pp257-270. New Haven: Yale University Press.

Hope, G.S. 1996. Quaternary change and historical biogeography of the Pacific Islands. In A. Keast and S.E. Miller (eds) The origin and evolution of Pacific Island biotas, New Guinea to Eastern Polynesia: patterns and processes, pp165-190. Amsterdam: SPB Academic Publishing.

McGlone, M.S., G.S. Hope, J.M.A. Chappell and P. Barrett 1996. Past climatic change in Oceania and Antarctica. In J. Bouma, G.I. Pearman and M.R. Manning (eds) Greenhouse: coping with climate change, pp81-99. Melbourne: CSIRO.

Read, J. and G.S. Hope 1996. Ecology of Nothofagus in New Guinea and New Caledonia. In T.T. Veblen, R.S. Hill and J. Read (eds) The ecology and biogeography of Nothofagus forests, pp200-256. New Haven: Yale University Press.

Kershaw, A.P., M.B. Bush, G.S. Hope, K.F. Weiss, J.G. Goldammer and R. Sanford 1997. The contribution of humans to past biomass burning in the tropics. In J. Clark, H. Cachier, J.G. Goldammer and B. Stocks (eds) Sediment records of biomass burning and global change, pp413-442. Berlin: Springer-Verlag. 
Hope, G. 1998. Early fire and forest change in the Baliem Valley, Irian Jaya, Indonesia. Journal of Biogeography 25:453-461.

Dickinson, W.R., D.V. Burley, P.D. Nunn, A. Anderson, G.S. Hope, A.D. Biran, C. Burke and S. Matararaba 1998. Geomorphic and archaeological landscapes of the Sigatoka Dune Site, Viti Levu, Fiji: Interdisciplinary investigations. Asian Perspectives 37:1.

Hope, G. and J. Pask 1998. Tropical vegetational change in the late Pleistocene of New Caledonia. Palaeogeography, Palaeoclimatology, Palaeoecology 142:1-21.

Hope, G. 1999. Vegetation and fire response to late Holocene human occupation in island and mainland north west Tasmania. Quaternary International 59:47-60.

Read, J., T. Jaffre, E. Godrie, G.S. Hope and J.M. Veillon 2000. Structural and floristic characteristics of some monodominant and adjacent mixed rainforests in New Caledonia. Journal of Biogeography 27:233-250.

Haberle, S.G., G.S. Hope and S. van der Kaars 2001. Biomass burning in Indonesia and Papua New Guinea: natural and human induced fire events in the fossil record. Palaeogeography, Palaeoclimatology, Palaeoecology 171:259-268.

Hope, G. 2001. Environmental change in the Late Pleistocene and later Holocene at Wanda site, Soroako, South Sulawesi, Indonesia. Palaeogeography, Palaeoclimatology, Palaeoecology 171:129-145.

Hope, G.S. 2002. The Late Quaternary of Kiritimati (Christmas) Island, Kiribati. In A.J. Anderson, H. Martinsson Wallin and P. Wallin (eds) The Prehistory of Kiritimati (Christmas) Island, Republic of Kiribati Excavations and analyses, pp111-118. Oslo: Kon-Tiki Museum Occasional papers.

Nunn, P.D., C. Ollier, G. Hope, P. Rodda, A. Omura and W.R. Peltier 2002. Late Quaternary sea-level and tectonic changes in northeast Fiji. Marine Geology 187:299-311.

Hope, G.S. 2003. The mountain mires of southern New South Wales and the Australian Capital Territory: their history and future. In B. Mackay (ed.) Proceedings of an International Year of the Mountains Conference, Jindabyne Nov 25-28, 2002, pp67-79. Canberra: Australian Alps Liaison Committee.

Hope, G.S., R. Hnatiuk and J.B. Smith 2003. Asia y Oceania: Los Ecosistemas Alpinos De Nueva Guinea Y El Sudeste De Asia (The alpine ecosystems of New Guinea and Southeast Asia). In R. Hofstede, P. Segarra and P.M. Vasconez (eds) Los Paramos del Mundo, pp245253. Quito: IUCN/EcoCiencia.

Whinam, J., G.S. Hope, B.R. Clarkson, R.P. Buxton, P.A. Alspach and P. Adam 2003. Sphagnum in peatlands of Australasia: Their distribution, utilisation and management. Wetlands Ecology and Management 11:37-49.

Bird, M.I., G. Hope and D. Taylor 2004. Populating PEP II: the dispersal of humans and agriculture through Austral-Asia and Oceania. Quaternary International 118-119:145-163.

Hope, G.S. 2004. Glaciation of Malaysia and Indonesia, excluding New Guinea. In J. Ehlers and P.L. Gibbard (eds) Quaternary glaciations - extent and chronology, Part III, Developments in Quaternary Science, pp211-214. Amsterdam: Elsevier.

Hope, G., A.P. Kershaw, S.v.d. Kaars, S. Xiangjun, P.-M. Liew, L.E. Heusser, H. Takahara, M. McGlone, N. Miyoshi and P.T. Moss 2004. History of vegetation and habitat change in the Austral-Asian region. Quaternary International 118-119:103-126.

Thomas, F.R., P.D. Nunn, T. Osborne, R. Kumar, F. Areki, S. Matararaba, D. Steadman, D. O'Day and G. Hope 2004. Recent archaeological findings at Qaranilaca Cave, Vanuabalavu Island, Fiji. Archaeology in Oceania 39:42-49.

Hope, G.S. 2005. The Quaternary in Southeast Asia. In A. Gupta (ed.) The physical geography of Southeast Asia, pp24-37. Oxford: Oxford University Press.

Hope, G.S. and K. Aplin 2005. Environmental change in the Aru Islands. In S. O'Connor, M. Spriggs and P. Veth (eds) The Archaeology of the Aru Islands, Eastern Indonesia, Terra Australis, pp25-40. Canberra: Pandanus Books. 
Hope, G.S. and S.G. Haberle 2005. The history of the human landscapes of New Guinea. In A. Pawley, R. Attenborough, J. Golson and R. Hide (eds) Papuan pasts: cultural, linguistic and biological histories of Papuan-speaking peoples, pp541-554. Canberra: Pacific Linguistics, The Australian National University.

Hope, G., J. Whinam and R. Good 2005. Methods and preliminary results of post-fire experimental trials of restoration techniques in the peatlands of Namadgi (ACT) and Kosciuszko National Parks (NSW). Ecological Management and Restoration 6:214-217.

O’Connor, S., K. Aplin, J. Pasveer and G.S. Hope 2005. Liang Nabulei Lisa: A Late Pleistocene and Holocene sequence from the Aru Islands. In S. O'Connor, M. Spriggs and P. Veth (eds) The Archaeology of the Aru Islands, Eastern Indonesia, Terra Australis, pp125-162. Canberra: Pandanus Books.

Prentice, M.L., G.S. Hope, K. Maryunani and J.A. Peterson 2005. An evaluation of snowline data across New Guinea during the last major glaciation, and area-based glacier snowlines in the Mt. Jaya region of Papua, Indonesia, during the Last Glacial Maximum. Quaternary International 138-139:93-117.

Read, J., G.S. Hope and R.S. Hill 2005. Phytogeography and climate analysis of Nothofagus subgenus Brassospora in New Guinea and New Caledonia. Australian Journal Botany 53:297-312.

Hope, G., U. Chokkalingam and S. Anwar 2005. The stratigraphy and fire history of the Kutai Peatlands, Kalimantan, Indonesia. Quaternary Research 64:407-417.

Stevenson, J. and G. Hope 2005. A comparison of late Quaternary forest changes in New Caledonia and northeastern Australia. Quaternary Research 64:372-383.

Anderson, A., R. Roberts, W. Dickinson, G. Clark, D. Burley, A.d. Biran, G. Hope and P. Nunn 2006. Times of sand: Sedimentary history and archaeology at the Sigatoka Dunes, Fiji. Geoarchaeology 21:131-154.

Heinsohn, T.E. and G.S. Hope 2006. The Torresian connections: Zoogeography of New Guinea. In J.R. Merrick, M. Archer, G.M. Hickey and M.S.Y. Lee (eds) Evolution and Biogeography of Australasian Vertebrates, pp71-93. Sydney: Auscipub.

Hope, G.S. 2006. Histories of wetlands in the Australian Capital Territory and the bog recovery program. In K. McCue, S. Lenz and S. Freidrich (eds) Caring for Namadgi Science and People. Proceedings of the NPA ACT Symposium Canberra May 2006, pp129-144. Canberra: National Parks Association ACT.

Hope, G.S., J. Coddington and D. O'Dea 2006. Estuarine development and human occupation at Bobundara Swamp, Tilba Tilba, New South Wales, Australia. In M. Lillie and S. Ellis (eds) Wetland Archaeology and environments: regional issues, global perspectives, pp258-274. Oxford: Oxbow.

Whinam, J. and G.S. Hope 2006. The peatlands of the Australasian Region. In G.M. Steiner (ed.) Mires from Siberia to Tierra Del Fuego, pp397-434. Stapfia 85, Zugleich Kataloge der Oberösterreichischen Landsmuseen, N.S.

Read, J., Jaffré, T., J.M. Ferris, S. McCoy and G.S. Hope 2006. Does soil determine the boundaries of monodominant rain forest with adjacent mixed rain forest and maquis on ultramafic soils in New Caledonia? Journal of Biogeography 33:1055-1065.

Fairbairn, A., G. Hope and G. Summerhayes 2006. Pleistocene occupation of New Guinea's highland and subalpine environments. World Archaeology 38:371-386.

Hope, G.S. 2007. Palaeoecology and palaeoenvironments of Papua. In A.J. Marshall and B.M. Beehler (eds) The ecology of Papua, pp255-266. Singapore: Periplus editions.

Hope, G.S. 2007. The history of human impact on New Guinea. In A.J. Marshall and B.M. Beehler (eds) The ecology of Papua, pp1087-1097. Singapore: Periplus editions.

Hope, G.S. and K.P. Aplin 2007. Paleontology. In A.J. Marshall and B.M. Beehler (eds) The ecology of Papua, pp246-254. Singapore: Periplus editions. 
Hope, G.S. and A.E. Hartemink 2007. Soils of Papua. In A.J. Marshall and B.M. Beehler (eds) The ecology of Papua, pp165-176. Singapore: Periplus editions.

Prentice, M. and G.S. Hope 2007. Climate of Papua. In A.J. Marshall and B.M. Beehler (eds) The ecology of Papua, pp177-195. Singapore: Periplus editions.

Donders, T.H., S.G. Haberle, G. Hope, F. Wagner and H. Visscher 2007. Pollen evidence for the transition of the Eastern Australian climate system from the post-glacial to the presentday ENSO mode. Quaternary Science Reviews 26:1621-1637.

Hope, G.S. and R.L. Clark 2008. A tale of two swamps: subalpine peatlands in the KellyScabby area of Namadgi National Park. In K. McCue and S. Lenz (eds) Corridors for survival in a changing world, pp61-76. Canberra: National Parks Association, ACT.

Power, M., J. Marlon, N. Ortiz, P. Bartlein, S. Harrison, F. Mayle, A. Ballouche, R. Bradshaw, C. Carcaillet, C. Cordova, S. Mooney, P. Moreno, I. Prentice, K. Thonicke, W. Tinner, C. Whitlock, Y. Zhang, Y. Zhao, A. Ali, R. Anderson, R. Beer, H. Behling, C. Briles, K. Brown, A. Brunelle, M. Bush, P. Camill, G. Chu, J. Clark, D. Colombaroli, S. Connor, A.L. Daniau, M. Daniels, J. Dodson, E. Doughty, M. Edwards, W. Finsinger, D. Foster, J. Frechette, M.J. Gaillard, D. Gavin, E. Gobet, S. Haberle, D. Hallett, P. Higuera, G. Hope, S. Horn, J. Inoue, P. Kaltenrieder, L. Kennedy, Z. Kong, C. Larsen, C. Long, J. Lynch, E. Lynch, M. McGlone, S. Meeks, S. Mensing, G. Meyer, T. Minckley, J. Mohr, D. Nelson, J. New, R. Newnham, R. Noti, W. Oswald, J. Pierce, P. Richard, C. Rowe, M. Sanchez Goñi, B. Shuman, H. Takahara, J. Toney, C. Turney, D. Urrego-Sanchez, C. Umbanhowar, M. Vandergoes, B. Vanniere, E. Vescovi, M. Walsh, X. Wang, N. Williams, J. Wilmshurst and J. Zhang 2008. Changes in fire regimes since the Last Glacial Maximum: an assessment based on a global synthesis and analysis of charcoal data. Climate Dynamics 30:887-907.

Hope, G.S., J. Stevenson and W. Southern 2009. Vegetation histories from the Fijian Islands: Alternative records of human impact. In G. Clark and A. Anderson (eds) The early prehistory of Fiji, Terra Australis, pp64-86. Canberra: ANU Press.

Hope, G. 2009. Environmental change and fire in the Owen Stanley Ranges, Papua New Guinea. Quaternary Science Reviews 28:2261-2276. 